\title{
Central adiposity among elderly women in a gerontology-geriatric unit
}

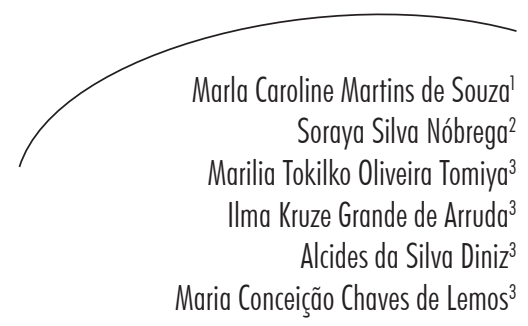

\section{Abstract}

Objective: To evaluate central adiposity in elderly women in a gerontology-geriatric care unit of the Universidade Federal de Pernambuco (the Federal University of Pernambuco). Method: A cross-sectional study involving a sample of 182 elderly women, aged from 60 to 89 years, who received care from January to July 2011, was performed. The variables analyzed were the socio-economic and demographic conditions, lifestyle, waist circumference (WC) and body mass index (BMI) of the women, as well as the occurrence of hypertension, diabetes mellitus and high total cholesterol levels. Yates' chi-squared test and Fisher's exact test were applied. A significance rate of $5 \%$ was adopted for the rejection of the null hypothesis. Results: Of the elderly women surveyed $82.4 \%$ had a WC signifying a large waist size, $57.2 \%$ were over-weight, $78.3 \%$ presented hypercholesterolemia, $63.2 \%$ had hypertension and $23.6 \%$ had diabetes. $61.5 \%$ were aged between 60 and 69 years old; $56 \%$ received up to two minimum salaries; $63.5 \%$ had less than eight years of schooling, $74.7 \%$ stated that they did not smoke, $87.9 \%$ did not drink alcohol; and 51.4 had sedentary habits. An association was observed between BMI and central adiposity (CA) ( $p=0.000)$. CA tended to be present around 1.2 times more frequently in elderly women with excess weight than among those who were not overweight. Conclusion: The high frequency of central adiposity and overweight indicates the susceptibility of this population to these factors. While no association with cardiovascular risk factors was observed, there is a clear need for monitoring by a multidisciplinary team, so as to identify and treat this debilitating condition, thereby contributing to the quality of life of this population.

\footnotetext{
Hospital das Clínicas da Universidade Federal de Pernambuco, Programa de Residência em Nutrição. Recife, Pernambuco, Brasil.

2 Universidade Federal de Pernambuco, Programa de Idoso - Núcleo de Atendimento ao Idoso. Recife, Pernambuco, Brasil.

3 Universidade Federal de Pernambuco, Departamento de Nutrição. Recife, Pernambuco, Brasil.
}

Keywords: Obesity Abdominal. Elderly. Cardiovascular Diseases. Abdominal Circumference. Body Mass Index. 


\section{INTRODUCTION}

Chronic non-communicable diseases include a wide spectrum of illnesses, including systemic arterial hypertension ( $\mathrm{SAH}$ ), type 2 diabetes mellitus (DM2), cardiovascular disease (CVD), respiratory, musculoskeletal and neuropsychiatric conditions and certain types of cancer. These, in turn, are directly related to functional disability among the elderly and a reduced quality of life. ${ }^{1}$

Obesity is a chronic disease characterized by excess adipose tissue and is related to several of the comorbidities listed above. In addition, overweight and obesity alter metabolism and biochemistry in all age groups, including the elderly, and affect both genders. ${ }^{2}$

The accumulation of adipose tissue in the abdominal region, also known as Central Adiposity (CA) or android obesity, is considered an independent risk factor for many morbidities, representing a more significant risk than other forms of body fat distribution. ${ }^{3}$ Various methods can be used to determine visceral adipose tissue, such as: a) Computed Tomography (CT) which, despite traditionally being considered the most efficient and accurate method, is impractical for routine use due to its high cost and the fact it subjects individuals to radiation; b) magnetic resonance imaging, which provides similar results to CT, but is even more prohibitively expensive for use in clinical practice and research and; c) Ultrasonography, which is a noninvasive method with good reproducibility that is fast, easy to use and a low cost option, and appears to be effective and have good applicability for the measurement of visceral fat, although specific equipment and a trained examiner are required. ${ }^{4}$ Given the lack of more precise methods, a more affordable alternative would be to measure Waist Circumference (WC) which indirectly determines visceral fat. ${ }^{5}$ This is often evaluated in clinical practice and is a simple and low cost measurement and an important signaler of metabolic complications and evaluator of cardiovascular risk, ${ }^{6-8}$ which suggests a frequent requirement for this assessment in the clinical and nutritional assessment of patients. ${ }^{11}$
The increase in the elderly population stimulates the need for studies to investigate the accumulation of abdominal fat in relation to the risk of metabolic complications. Therefore, the present study aimed to evaluate central adiposity among elderly persons receiving care in a gerontology-geriatric unit.

\section{METHOD}

A cross-sectional study was conducted using a database that forms part of a project currently in progress at the Núcleo de Atenção ao Idoso (Elderly Health Center) (NAI), which is an outpatient unit linked to the Programa do Idoso (Elderly Program) (PROIDOSO) of the PróReitoria de Extensão (Office of the Dean for Extension Studies) of the Universidade Federal de Pernambuco (Pernambuco Federal University) (UFPE). The NAI is aimed at the individual and group care of elderly patients aged 60 or over, with the premise of promoting and encouraging actions to improve the health status of patients, considering the resources available and through work in multidisciplinary teams.

The sample consisted of 182 elderly persons, selected by convenience, who were residents of the city of Recife and received healthcare at the NAI nutrition clinic from January to July 2011.

Amputees, elderly patients with catabolic conditions such as hyperthyroidism, acquired immunodeficiency syndrome or cancer, and users of drugs such as corticosteroids, immunosuppressants and hormone therapy, as well as individuals with the presence of edema or ascites, were excluded from the study.

Data relating to socioeconomic and demographic conditions was collected through interviews with the patient using the Associação Brasileira de Estudos Populacionais (Brazilian Association for Populational Studies) (ABEP) questionnaire. ${ }^{9}$ This instrument was constructed with the use of statistical techniques to define large classes segmented by purchasing power and was directly applied with the patients during outpatient visits. 
Waist circumference was measured with the patient standing, using a non-extensible tape with a $0-150 \mathrm{~cm}$ scale and resolution of $0.1 \mathrm{~cm}$. The tape circled the individual at the midpoint between the last rib and the iliac crest and the reading was taken at the moment of exhalation. ${ }^{10}$

Weight and height measurements were taken in duality according to the technique proposed by Lohman. ${ }^{11}$ The participants were weighed using a Filizola ${ }^{\circledR}$ platform type digital electronic scale, with a maximum capacity of $150 \mathrm{~kg}$ and precision of $100 \mathrm{~g}$. Height was measured with the patient barefoot, in the Frankfurt position, with a stadiometer attached to a platform scale with a capacity of $1.90 \mathrm{~m}$ and an accuracy of $1 \mathrm{~mm}$. For data consistency, measurements with differences greater than $100 \mathrm{~g}$ for weight, $0.5 \mathrm{~cm}$ for height and $0.1 \mathrm{~cm}$ for waist circumference were repeated. ${ }^{12}$

For assessment of the risk of metabolic complications cutoff points for CA in Caucasian women of $<80 \mathrm{~cm}$ (no risk); $\geq 80 \mathrm{~cm}$ (increased risk) and $\geq 88 \mathrm{~cm}$ (substantially increased risk) were used. ${ }^{13}$ The Body Mass Index (BMI) for the elderly was used to evaluate nutritional status in accordance with Lipschitz, ${ }^{14}$ whose classification values are defined as low weight: $<22 \mathrm{~kg} / \mathrm{m}^{2}$ eutrophic: 22 to $27 \mathrm{~kg} / \mathrm{m}^{2}$, overweight: $>27 \mathrm{~kg} / \mathrm{m}^{2}$.

Data on life habits (alcohol consumption, tobacco use and physical activity) was collected through interviews with the patient. A questionnaire specifically designed for the research subject was used. Smoking and alcohol consumption was defined according to the use of both, irrespective of frequency. Physical activity was defined based on the time criterion for the definition of a sedentary condition, with elderly persons who practiced less than 150 minutes of moderate physical activity per week classified as sedentary. ${ }^{15}$ Data on medical condition was also collected: the presence of hypertension, a systolic blood pressure greater than or equal to $140 \mathrm{mmHg}$ and/or diastolic blood pressure greater than or equal to $90 \mathrm{mmHg}$ in individuals who were not using antihypertensive medication in accordance with guidelines. ${ }^{16}$ Elderly women who used antihypertensive medication were also categorized in the hypertensive group. For DM2, the following diagnostic criteria were used: fasting glucose $\geq 126 \mathrm{mg} / \mathrm{dL}$ and/or the occurrence of polyuria, polydipsia and weight loss, plus random blood glucose levels above 200 $\mathrm{mg} / \mathrm{dL} .{ }^{17}$ For hypercholesterolemia, lipid profile reference values for adults older than 20 years were used(CT $>200 \mathrm{mg} / \mathrm{dL}) .^{18}$

The database was tabulated in the Microsoft Office Excel 2010 program and statistical analysis was performed using the Epi Info program version 6.04 [WHO/CDC, Atlanta, GE, USA] and SPSS version 13.0 [SPSS INC., Chicago, IL, USA]. Statistical analysis was divided into two steps. Firstly, descriptive analysis (univariate) was carried out to characterize the distribution of the occurrence of events, including the frequency of each study variable and employing a 95\% confidence interval, and then bivariate analysis of the relationship between the dependent variable (central adiposity) and the independent variables was performed, allowing the prevalence ratio (PR) and respective 95\% confidence interval to be determined for each characteristic studied. The chi-squared test was used to assess the association between variables, and when this was not applicable Fisher's exact test was used. A 5\% significance level was adopted for the rejection of the null hypothesis.

The study was duly approved by the Ethics Committee of the Pernambuco Federal University, under CAAE 413/11.

\section{RESULTS}

Of the 182 elderly women, $61.5 \%$ aged between 60 and 69 . The per capita income of $56 \%$ of the study population was lower than between 1 and 2 minimum wages. In terms of the consumption of alcohol and smoking, most individuals described not having such habits, representing $87.9 \%$ and $74.7 \%$, respectively.

Some losses occurred at the time of data collection for the variables of education, physical 
activity and high cholesterol levels, resulting in a final sample of 181 for the first two variables and 180 for hypercholesterolemia. Regarding the educational and physical activity levels of the population studied, $63.5 \%$ reported having studied for less than 8 school years and $51.4 \%$ said they performed no physical activity.

With respect to the comorbidities associated with aging, $78.3 \%$ of respondents in the sample had hypercholesterolemia, $63.2 \%$ suffered from hypertension and $23.6 \%$ were diagnosed with DM2.

In terms of nutritional status, $57.2 \%$ of the women were overweight and $82.4 \%$ had a very high waist circumference measurement.

Table 3 shows the association between central adiposity and associated factors, with a significant association found only with overweight.

Table 1. Socioeconomic, demographic and clinical characteristics of elderly women receiving care at the nutrition clinic of the Elderly Care Center. Recife, Pernambuco, 2011.

\begin{tabular}{llll}
\hline Variables & $\mathrm{n}$ & $\%$ & $\mathrm{CI}_{95 \%}$ \\
\hline Age (years) & 112 & 61.5 & $54.02-68.56$ \\
$\geq 60$ to 69 & 70 & 38.5 & $31.44-45.97$ \\
$\quad>69$ & & & \\
Family Income (minimum salary) & 102 & 56.0 & $48.50-63.32$ \\
$\leq 2$ & 80 & 44.0 & $36.67-51.49$ \\
$>2$ & & & \\
Education (study) & 115 & 63.5 & $56.02-70.45$ \\
$\leq 8$ years & 66 & 36.5 & $29.54-43.97$ \\
$>8$ years & & & \\
Smoker & 46 & 25.3 & $19.27-32.35$ \\
$\quad$ Yes & 136 & 74.7 & $67.65-80.73$ \\
No & & & \\
Alcohol Consumption & 22 & 12.1 & $7.90-17.9$ \\
$\quad$ Yes & 160 & 87.9 & $82.06-92.10$ \\
No & & & \\
Performs physical activity & 88 & 48.6 & $41.17-56.12$ \\
Yes & 93 & 51.4 & $43.87-58.82$ \\
No & & &
\end{tabular}


Continuation of Table 1

\begin{tabular}{llcc}
\hline Variables & $\mathrm{n}$ & $\%$ & $\mathrm{CI}_{95 \%}$ \\
\hline SAH $^{*}$ & & & $55.70-70.11$ \\
Yes & 115 & 63.2 & $29.89-44.30$ \\
No & 67 & 36.8 & \\
DM2** & & & $17.79-30.60$ \\
Yes & 43 & 23.6 & $69.40-82.21$ \\
No & 139 & 76.4 & \\
Elevated TC *** & & & $71.45-83.97$ \\
Yes & 141 & 78.3 & $16.02-28.54$ \\
No & 39 & 21.7 & \\
\hline
\end{tabular}

*SAH: Systemic Arterial Hypertension (systolic arterial pressure $\geq 140 \mathrm{mmHg}$ and/or diastolic arterial pressure $\geq 90 \mathrm{mmHg}$ ); **DM2: Type 2 Diabetes Mellitus (fasting glucose $\geq 126 \mathrm{mg} / \mathrm{dL}$ and/or casual glucose $>200 \mathrm{mg} / \mathrm{dL}$ ); *** CT: Heightened Total Cholesterol (CT $>200 \mathrm{mg} / \mathrm{dL}$ ).

Table 2. Characterization of nutritional status according to the body mass index and waist circumference of elderly women receiving care at the nutrition clinic of the Elderly Care Center. Recife, Pernambuco, 2011.

\begin{tabular}{|c|c|c|c|}
\hline Variables & $\mathrm{n}^{\mathrm{o}}$ & $\%$ & $\mathrm{CI}_{95 \%} *$ \\
\hline \multicolumn{4}{|l|}{$\mathrm{WC}^{* *}(\mathrm{~cm}$} \\
\hline No risk ${ }^{1}$ & 16 & 8.8 & $5.27-14.13$ \\
\hline Increased risk ${ }^{2}$ & 16 & 8.8 & $5.27-14.13$ \\
\hline Substantially increased risk ${ }^{3}$ & 150 & 82.4 & $75.93-87.50$ \\
\hline \multicolumn{4}{|l|}{$\mathrm{BMI} * * *\left(\mathrm{~kg} / \mathrm{m}^{2}\right)$} \\
\hline Underweight ${ }^{4}$ & 13 & 7.1 & $4.06-12.17$ \\
\hline Eutrophic $^{5}$ & 65 & 35.7 & $28.86-43.19$ \\
\hline Overweight $^{6}$ & 104 & 57.2 & $49.60-64.38$ \\
\hline
\end{tabular}

$* \mathrm{CI}_{95 \%}: 95 \%$ Confidence Interval; $* *$ WC: Waist Circumference; $* * *$ BMI: body mass index; No risk ${ }^{1}:<80 \mathrm{~cm}^{2}$ Increased risk ${ }^{2}: \geq 80 \mathrm{~cm}^{2}$ Substantially increased risk ${ }^{3}: \geq 88 \mathrm{~cm} ;$ Underweight $^{4}:<22 \mathrm{~kg} / \mathrm{m}^{2} ;$ Eutrophic ${ }^{5}: 22$ to $27 \mathrm{~kg} / \mathrm{m}^{2} ;$ Overweight $^{6}:>27 \mathrm{~kg} / \mathrm{m}^{2}$. 
Table 3. Association between central adiposity and the studied variables of elderly women receiving care at the nutrition clinic of the Elderly Care Center. Recife, Pernambuco, 2011.

\begin{tabular}{|c|c|c|c|c|c|c|c|c|}
\hline \multirow[t]{2}{*}{ Variables } & \multirow{2}{*}{$\begin{array}{l}\text { Total } \\
\mathrm{N}\end{array}$} & \multicolumn{2}{|c|}{ In adequate } & \multicolumn{2}{|c|}{ Adequate } & \multirow[t]{2}{*}{$p \#$} & \multirow[t]{2}{*}{ PR } & \multirow[t]{2}{*}{$\mathrm{CI}_{95 \%}$} \\
\hline & & $\mathrm{N}$ & $\%$ & $\mathrm{n}$ & $\%$ & & & \\
\hline \multicolumn{9}{|l|}{ Elevated $\mathrm{CT}^{* * *}$} \\
\hline Yes & 141 & 127 & 90.1 & 14 & 9.9 & 0.528 & 0.95 & $(0.87-1.04)$ \\
\hline No & 39 & 37 & 94.9 & 2 & 5.1 & & & \\
\hline \multicolumn{9}{|l|}{ BMI } \\
\hline Excess & 105 & 104 & 99.0 & 1 & 1.0 & 0.000 & 1.2 & $(1.1-1.4)$ \\
\hline No excess & 77 & 62 & 80.5 & 15 & 19.5 & & & \\
\hline \multicolumn{9}{|l|}{$\mathrm{SAH}^{*}$} \\
\hline Yes & 115 & 106 & 92.2 & 9 & 7.8 & 0.741 & 1.0 & $(0.9-1.1)$ \\
\hline No & 67 & 60 & 89.6 & 7 & 10.4 & & & \\
\hline \multicolumn{9}{|l|}{$\mathrm{DM} 2 * *$} \\
\hline Yes & 43 & 41 & 95.3 & 2 & 4.7 & 0.366 & 1.1 & $(1.0-1.2)$ \\
\hline No & 139 & 125 & 89.9 & 14 & 10.1 & & & \\
\hline \multicolumn{9}{|l|}{ Educational Level } \\
\hline$\leq 8$ years & 115 & 104 & 90.4 & 11 & 9.6 & 0.86 & 0.98 & $(0.9-1.1)$ \\
\hline$>8$ years & 66 & 61 & 92.4 & 5 & 7.6 & & & \\
\hline \multicolumn{9}{|l|}{ Income } \\
\hline Up to 2 salaries & 101 & 95 & 94.1 & 6 & 5.9 & 0.21 & 1.1 & $(1.0-1.2)$ \\
\hline 2 salaries & 81 & 71 & 87.7 & 10 & 12.3 & & & \\
\hline \multicolumn{9}{|l|}{ Physical Activity } \\
\hline Yes & 88 & 80 & 90.9 & 8 & 9.1 & 0.88 & 1.0 & $(0.9-1.1)$ \\
\hline No & 93 & 85 & 91.4 & 8 & 8.6 & & & \\
\hline
\end{tabular}

*SAH: Systemic Arterial Hypertension (systolic arterial pressure $\geq 140 \mathrm{mmHg}$ and/or diastolic arterial pressure $\geq 90 \mathrm{mmHg}$ ); **DM2: Type 2 Diabetes Mellitus (fasting glucose $\geq 126 \mathrm{mg} / \mathrm{dL}$ and/or casual glucose $>200 \mathrm{mg} / \mathrm{dL}$ ); $* * *$ CT: Elevated Total Cholesterol (CT $>200 \mathrm{mg} / \mathrm{dL}$ ); \#p<0.05 


\section{DISCUSSION}

The characterization of health care specifically for the elderly requires an evaluation of the population receiving treatment in order to observe characteristics that are peculiar to the clients in question. In the present study, the fact that the sample was composed only of women reflects their interest in healthcare, which is also seen in primary health care. Such evidence corroborates findings in existing literature which identify greater female demand for health services. ${ }^{19}$

With regard to the age of the study group, the highest frequency of elderly persons in the healthcare unit was in the 60 to 69 year age group, which seems to indicate that this population can still enjoy greater autonomy and independence in this period of life.

It was found that half of the sample of the present study did not practice physical activity, which contributes to increased health risks. Siqueira et al. ${ }^{20}$ found a prevalence of a sedentary lifestyle of around $58 \%$ for elderly persons, similar to the values found in the present study. With regard to limiting factors for the practice of physical activity by elderly women, Fuchs et al. ${ }^{21}$ concluded that cognitive capacity, frailty resulting from reduced anabolic hormonal activity and a chronic inflammatory state culminate in a self-sustained energy reduction cycle, weight loss, inactivity, low food intake and sarcopenia. Physical inactivity, according to literature, is one of the risk factors that most triggers the onset of chronic diseases, when associated with poor diet and tobacco use. ${ }^{20}$

Smoking and alcohol consumption were observed in lower proportions in the sample analyzed. This may suggest an increased care and concern for health in this elderly group. Similar findings were observed in the study by Ferreira et al. ${ }^{22}$ who analyzed cardiovascular risk factors in 418 elderly users of the Sistema Único de Saúde (the Unified Health System) and found that a minority smoked or consumed alcohol. Such bad living habits are important cardiovascular risk factors and feature in 7 of the 14 leading causes of death among the elderly, constituting a major public health problem today. ${ }^{1-}$

The anthropometric variables featured in the present study revealed that more than half of the analyzed sample was overweight and over $80 \%$ had a greatly increased risk of metabolic complications, according to the assessment of BMI and WC, respectively, corroborating results described by other authors. ${ }^{8,23,24}$

The findings of the present study showed a significant association between overweight and central adiposity $(\mathrm{PR}=1.2)$. A study by Santos \& Sichieri ${ }^{3}$ found that there was a strong correlation between WC and BMI in the group of age of older between 60 to 70 years $(r=0.76 ; p=0.003)$. Previato et al., ${ }^{25}$ who evaluated the same anthropometric variables, found that BMI was significantly associated with WC $(\mathrm{r}=0.87 ; p<0.001)$.

Castro $^{26}$ reported that the aging process is an important influence on the increase of adipose tissue in the abdominal region, as the elderly undergo changes in body composition as a natural factor of senescence and/or due to the occurrence of metabolic disorders. Changes in body composition lead to the redistribution of body fat from the limbs to the torso, or in other words, becoming more central, resulting in increased visceral adiposity in elderly persons in general, with this process being more significant in women than in men. From these body changes, the summation of cardiovascular risk factors can lead to death.

The lack of an association between central adiposity and the cardiovascular risk factors found in this study was an unexpected finding, since several studies ${ }^{2,27-33}$ have described opposite results. This finding may be explained by the size of the sample assessed in the present study. The Diabetes Epidemiology: Collaborative analysis of Diagnostic criteria in Europe (DECODE) study found that most anthropometric measurements (WC, WHR and waist-height ration) that identify abdominal obesity were more effective than $\mathrm{BMI}$ in predicting cardiovascular mortality. ${ }^{34}$ 
Warren Andersen et al. ${ }^{27}$, in a cohort study conducted in China with the aim of examining the relationship between central adiposity and waist-hip ratio (WHR) and risk of death, found that both men and women with a WHR in the bottom quintile had a 1.5 times greater risk of death than those in the first quintile, highlighting the damaging association between high central adiposity and death. This positive association is observed regardless of age, comorbidity, or smoking among men.

Cabrera and $\mathrm{Jacob}^{2}$ evaluated 847 elderly persons in an outpatient clinic and found an association for BMI and WHR with DM, SAH, hypercholesterolemia, low cholesterol (HDL-C), hypertriglyceridemia, social class, physical activity and smoking. Jansen and Katzmarzyk ${ }^{30}$ found that central adiposity is a major risk factor for the development of cardiovascular diseases, dyslipidemias, diabetes, metabolic syndrome and some forms of cancer, indicating a significant risk in relation to other measures of body fat distribution.

The possible mechanism for this relationship between central adiposity and cardiovascular risk factors can be justified by the fact that intraabdominal adipocytes are likely to release their free fatty acids directly into the portal vein, exposing the liver to high concentrations of such fatty acids, which can lead to hyperinsulinemia, dyslipidemia and hypertension. In addition, adipose tissue, especially abdominal, secrets substances (adipokines) that can promote the development of chronic diseases. ${ }^{28}$

Insulin, hypertriglyceridemia and cholesterol fractions were not analyzed in the present study due to the use of a database which did not include such information. This may be considered a limitation, as this data could further enrich the results.
Although increased cardiovascular mortality can only be demonstrated in longitudinal studies, the findings of this study suggest that the diagnosis of overweight based on BMI and the evaluation of central adiposity can help define an increased risk subgroup among the elderly in a simple and effective manner, which may support local interventions with lower operating costs that contribute to the prevention of CVD through effective actions involving multidisciplinary teams.

\section{CONCLUSION}

The high frequency of increased central adiposity and overweight among the elderly found in this study indicates the susceptibility of this population. The aging process causes functional disorders such as the reduction of muscle mass and increased fat tissue, which are also influenced by poor eating habits and a sedentary lifestyle, common characteristics related to the industrialization and modernization of society. Despite the lack of an association, it is known that overweight and an excess of centralized fat are cardiovascular risk factors, highlighting the importance of the use of multidisciplinary teams in the gerontology-geriatric unit in question, with the implementation of programs that prevent and control excessive weight gain. Therefore, further studies are needed to elucidate the association between central adiposity and cardiovascular risk factors among the elderly.

\section{ACKNOWLEDGEMENTS}

The authors would like to thank the Atenção ao Idoso da Universidade Federal de Pernambuco (the Elderly Health Center of the Federal University of Pernambuco) (NAI-UFPE). 


\section{REFERENCES}

1. Felipe LK, Zimmermann A. Doenças crônicas degenerativas em idosos: dados fisioterapêuticos. Rev Bras Promoç Saúde 2011;24(3):221-7.

2. Cabrera MAS, Jacob Filho W. Obesidade em idosos: prevalência, distribuição e associação com hábitos e co-morbidades. Arq Bras Endocrinol Metabol 2001;45(5):494-501.

3. Santos DM, Sichieri R. Índice de massa corporal e indicadores antropométricos de adiposidade em idosos. Rev Saúde Pública 2005;39(2):163-8.

4. Petribu MMV, Pinho CPS, Cabral PC, Arruda IGA, Melo AMCA. Métodos de avaliação da gordura abdominal. Rev Bras Nutr Clín 2012;27:257-63.

5. Rezende F, Rosado L, Franceschinni S, Rosado G, Ribeiro R, Marins JCB. Revisão crítica dos métodos disponíveis para avaliar a composição corporal em grandes estudos populacionais e clínicos. Arch Latinoam Nutr 2007;57(4):327-34.

6. Lima CG, Basile LG, Da Silveira JQ, Vieira PM, De Oliveira MRM. Circunferência da Cintura ou Abdominal? Uma Revisão Crítica dos Referenciais Metodológicos. Rev Simbio-Logias 2011;4(6):108-31.

7. Damascena LL, Pereira Neto N, Pereira VA. Correlação entre Obesidade Abdominal, IMC e Risco Cardiovascular. In: Centro de Ciências da Saúde, Departamento de Educação Física. $11^{\circ}$ Encontro de Iniciação à Docência; 9-11 abr 2008; João Pessoa, Paraíba. João Pessoa: UFPB; 2008.

8. Egewarth V, Borges FM, Lopes AB, Lüdke M, Vargas SS, Alscher S, et al. Avaliação da circunferência abdominal em idosos residentes em uma área adstrita a uma Unidade Básica de Saúde. In: $4^{\circ}$ Salão de Iniciação Científica; 2005 [sem local]. Porto Alegre: PUCRS; 2005.

9. Associação Brasileira de Empresas de Pesquisa. Critério de Classificação Econômica Brasil. Dados com base no Levantamento Sócio Econômico 2009IBOP. Jardim Paulista: ABEP; 2011.

10. World Health Organization. Obesity: preventing and managing the global epidemic. Geneve: WHO; 1998.

11. Lohman TG, Roche AF, Martorell R. Anthropometric Standardisation Reference Manual. Champaign: Human Kinetics Books; 1988.

12. Frisancho AR. Anthropometric Standards for the Assessment of Growth and Nutritional Status. An Arbor: University of Michigan; 1990.
13. Sociedade Brasileira de Cardiologia; Sociedade Brasileira de Endocrinologia e Metabologia. 1ª Diretriz Brasileira de diagnóstico e tratamento da síndrome metabólica. Arq Bras Cardiol 2005;suppl 1:1-28.

14. Lipshitz DA. Screening for nutritional status in the elderly. Prim Care 1994;2(1)1:55-67.

15. World Health Organization. Global recommendations on physical activity for health. Genebra: WHO; 2010.

16. Sociedade Brasileira de Cardiologia. $6^{a}$ Diretrizes Brasileiras de Hipertensão. Rev Bras Hipertens 2010;17(1): 1:51.

17. American Diabetes Association. Standards of Medical Care in Diabetes - 2015: Summary of Revisions. Diabetes Care 2015;38(Suppl 1):4-4.

18. Sociedade Brasileira de Cardiologia. $5^{\text {a }}$ Diretriz Brasileira de Dislipidemias e Prevenção da Aterosclerose. Arq Bras Cardiol 2013;101(4 Supl. 1):1-36.

19. Pimentel IRS, Coelho BCC, Lima JC, Ribeiro FG, Sampaio FPC, Pinheiro RP, et al. Caracterização da demanda em uma Unidade de Saúde da Família. Rev Bras Med Fam Comunidade 2011;6(20):175-81.

20. Siqueira FV, Facchini LA, Piccini RX, Tomasi E, Thumé E, Silveira DS, et al. Atividade física em adultos e idosos residentes em áreas de abrangência de unidades básicas de saúde de municípios das regiões sul e nordeste do Brasil. Cad Saúde Pública 2008;24(1):39-54.

21. Fuchs ARCN, Mastrocolla LE, Moura FR, Pelaquimet RL. Atividade física em mulheres muito idosas: fatores limitantes. Rev DERC 2015;21(1):12-4.

22. Ferreira CCC, Peixoto MRG, Barbosa MA, Silveira EA. Prevalência de fatores de risco cardiovascular em idosos usuários do Sistema Único de Saúde de Goiânia. Arq Bras Cardiol 2010;95(5):621-8.

23. Teixeira SDC, Coutinho RCNC, Coelho RL, Ribeiro SV, Barbosa LS. Excesso de peso em idosos residentes em instituições de longa permanência de Goiânia, Goiás. Brasília Méd 2012;49(4):250-7.

24. Buzzachera CF, Krause MP, Elsangedy HM, Hallage T, Granato P, Krinski K, et al. Prevalência de sobrepeso e obesidade geral e central em mulheres idosas da cidade de Curitiba, Paraná. Rev Nutr [Internet] 2008 [acesso em 08/04/2015];21(5)525-33. Disponível em: http:// www.scielo.br/scielo.php?script=sci_arttext\&pid $=$ S1415-52732008000500005; 
25. Previato HDRA, Dias APV, Nemer ASA, Nimer M. Associação entre índice de massa corporal e circunferência da cintura em idosas, Ouro Preto, Minas Gerais, Brasil. Nutr Clín Diet Hosp 2014;34(1):25-30.

26. Castro DGC. Intervenção na obesidade em idosos [monografia]. São Paulo: Universidade de São Paulo, Hospital das Clínicas; 2005.

27. Andersen SW, Shu XO, Gao YT, Zhang X, Cai H, Yang $G$, et al. Prospective cohort study of central adiposity and risk of death in middle aged and elderly chinese. PLoS ONE 2015;10(9):1-7.

28. Song X, Jousilahti P, Stehouwer CDA, Söderberg S, Onat A, Laatikainen T, et al. Cardiovascular and allcause mortality in relation to various anthropometric measures of obesity in Europeans. Nutr Metab Cardiovasc Dis 2015;(25):295-304.

29. Lim RBT, Chen C, Naidoo N, Gay G, Tang WE, Seah D, et al. Anthropometrics indices of obesity, and all-cause and cardiovascular disease-related mortality, in an Asian cohort with type 2 diabetes mellitus. Diabetes Metab [Internet] 2015 [acesso em 18/07/2016];41(4):291-300. Disponível em:http:// dx.doi.org/10.1016/j.diabet.2014.12.003
30. Jansen I, Katzmarzyk PT, Ross R. Body mass index, waist circumference, and health risk. Arch Intern Med 2002;162(18):2074-79.

31. Cerhan JR, Moore SC, Jacobs EJ, Kitahara CM, Rosenberg PS, Adami H-O, et al. A pooled analysis of waist circumference and mortality in 650,000 adults. Mayo Clin Proc 2014;89:335-45.

32. Liu Y, Qi LT, Ma W, Yang Y, Meng L, Zhang BW, et al. Correlation between anthropometric parameters and arteriosclerosis biomarker in the middle-aged and the elderly. Beijing Da Xue Xue Bao 2014;46(3):455-9.

33. Kabat GC, Heo M, Van Horn LV, Kazlauskaite R, Getaneh A, Ard J, et al. Longitudinal association of anthropometric measures of adiposity with cardiometabolic risk factors in postmenopausal women. Ann Epidemiol 2014;24(12):896-902.

34. Song X, Jousilahti P, Stehouwer CD, Söderberg $\mathrm{S}$, Onat A, Laatikainen T, et al. Comparison of various surrogate obesity indicators as predictors of cardiovascular mortality in four European populations. Eur J Clin Nutr 2013;67(12):1298-302.

Received: August 24, 2015

Revised: July 09, 2016

Accepted: August 03, 2016 